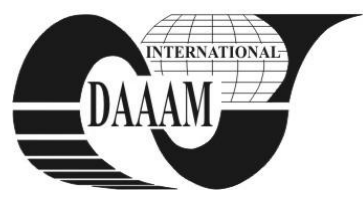

Annals of DAAAM for 2011 \& Proceedings of the 22nd International DAAAM Symposium, Volume 22, No. 1, ISSN 1726-9679 ISBN 978-3-901509-83-4, Editor B. Katalinic, Published by DAAAM International, Vienna, Austria, EU, 2011 Make Harmony between Technology and Nature, and Your Mind will Fly Free as a Bird Annals \& Proceedings of DAAAM International 2011

\title{
EFFECT OF RISK MANAGEMENT IMPLEMENTATION ON PRODUCTIVITY IMPROVEMENT
}

\author{
FENOLLERA, M[aria] \& LORENZO, J[aime]
}

\begin{abstract}
The companies from the naval sector are subject to a strong pressure from competitors and clients; this results in a high level of exigency in the execution of their projects. Within this framework, the application of the existing best practices and the use of worldwide project management standards become key pieces for these companies. This article puts forward the experiences gathered from the adaptation of the PMI methodology to a SME from Galician naval auxiliary industry. It deals with the different risk management implementation stages of a strategic project, showing the advantages and the keys to the project's success.

Key words: adaptation, SME, naval sector, risks, PMI
\end{abstract}

\section{INTRODUCTION}

Much has been written about risk management in big companies but there is little bibliography on the use of the PMI methodology in SME. Examples are the studies of Delisle \& StPierre (2003), Blanc-Alquier \& Lagasse-Tignol (2006) and Rosu et al. (2010) but their application is restricted and is usually developed for project-oriented organizations.

The main problem for a SME to implement this kind of methodologies is that the existing standards for project management were intended for large projects. In this project, the client has "guided" the SME in a suitable risk management implementation. The achievement has been to adapt the PMI methodology to create its own one adapted to the company's special characteristics. In addition to delivering the order fulfilling its specifications, this was about implementing a simple, agile risk management, adapted to the nature of the project, organization's sector and company culture that could be applied to future projects. The aim was to find proper indicators for particular processes and to find methodology that would help identify those (Nagyova \& Pacaiova, 2009).

\section{CASE STUDY}

The Project we are about to analyze, "design and manufacture of 8 fender davits, was a significant strategic project in 2010. It began as such at the request of the customer, who follows the guidelines of Project Management Body of Knowledge (PMBok, 2008). This project's success was a milestone: it meant the introduction of the SME into a highly competitive new market.

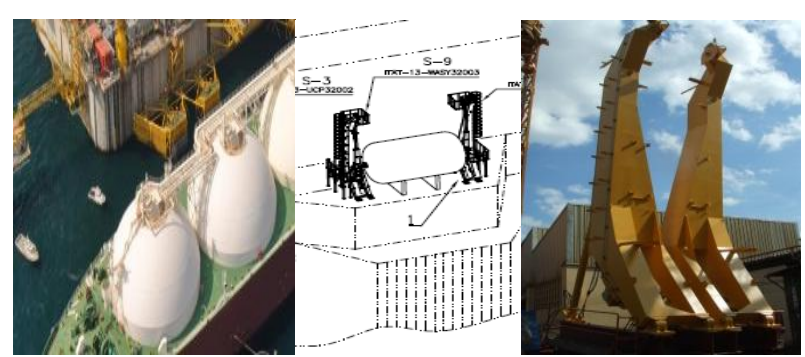

Fig. 1. Technical characteristics

\begin{tabular}{|l|l|}
\hline \multicolumn{2}{|c|}{ DESIGN AND MANUFACTURE OF FENDER DAVITS } \\
\hline Order: & 4 pairs of davits for gas extraction platform \\
\hline Customer: & Leading Norwegian multinational company \\
\hline Delivery: & One year from order's acceptance \\
\hline Price: & $1.300 .000 €(22 \%$ of turnover $)$ \\
\hline Estimated cost: & $800,000 €(38 \%$ profit $)$ \\
\hline Delay records: & 30 -day average delay \\
\hline Cost records: & $15 \%$ increase from initial budget \\
\hline
\end{tabular}

Tab. 1. Project's initial considerations

\subsection{Risk Management Plan (RMP)}

Describe the procedure for the identification, analysis, prioritization and monitoring of the risks associated to the project (figure 2).

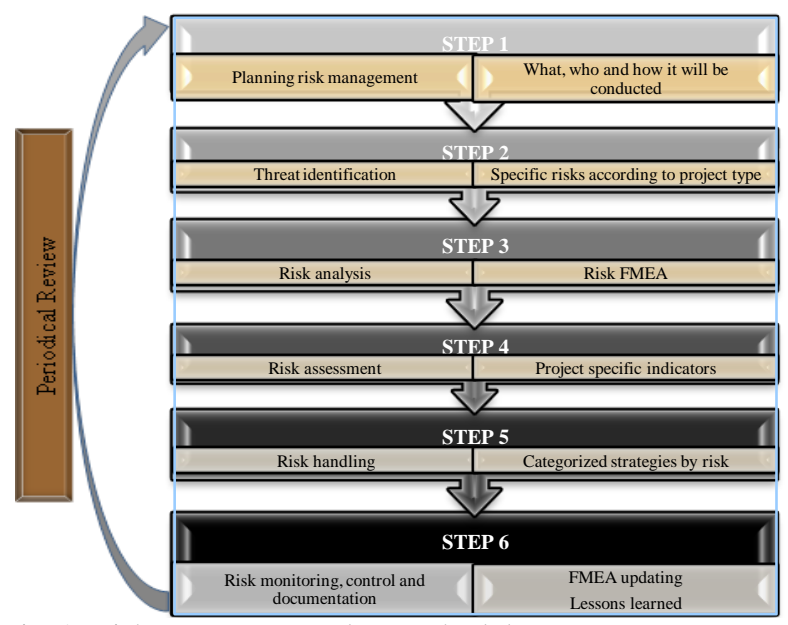

Fig. 2. Risk Management Plan Methodology

\subsection{Risk Management Planning}

The process covered the following aspects:

Organization: an external auditor was hired by customer; he acted as the project's risk management centre, coordinating the agents implied and integrating the management of the risks identified in the subprojects.

Roles and responsibilities: RMP chart defines three figures and their responsibilities:

- Risk management coordinator: external auditor hired by customer.

- Subproject Manager: responsible for each subproject.

- Member of team project: members of each team assigned.

Activities: actions defined in two process groups: planning and implementation; indicating for each of them which techniques were used, who the responsible is, who takes part in that activity, which deliverable is obtained and how often each activity is conducted (table 2).

Action procedures: course of action was divided into two procedures according to the risk management phase:

- Identification, analysis and action plan

- Monitoring and control. 


\begin{tabular}{|l|l|l|l|}
\hline When & Planning & Planning & Planning \\
\hline Action & Risk Identification & $\begin{array}{l}\text { Risk } \\
\text { Identification }\end{array}$ & $\begin{array}{l}\text { Qualitative Risk } \\
\text { Analysis }\end{array}$ \\
\hline Technique & Brainstorming & Checklist & FMEA \\
\hline Manager & Project manager & $\begin{array}{l}\text { Project } \\
\text { manager }\end{array}$ & Project manager \\
\hline Participants & Team project & Team project & Team project \\
\hline Deliverables & $\begin{array}{l}\text { Risk Register } \\
\text { Document }\end{array}$ & $\begin{array}{l}\text { Risk } \\
\text { Register } \\
\text { Document }\end{array}$ & $\begin{array}{l}\text { Risk Register, } \\
\text { probability \& impact } \\
\text { matrix, non-priority } \\
\text { risks list }\end{array}$ \\
\hline Periodicity & $\begin{array}{l}\text { Once at beginning; } \\
\text { also at every } \\
\text { monitoring meeting }\end{array}$ & $\begin{array}{l}\text { Once at } \\
\text { beginning of } \\
\text { project }\end{array}$ & $\begin{array}{l}\text { Once at beginning of } \\
\text { project; at every } \\
\text { monitoring meeting }\end{array}$ \\
\hline
\end{tabular}

Tab. 2. Risk Management Planning Process Activities

Controls: Risk Management Coordinator reviewed actions associated to risks monthly through the Internal Monitoring Report (IMR) and specifically when high exposure risks arose. . Metrics: measures including enough information to alert on potential harm and help identify all kinds of risks (table 3 ).

\begin{tabular}{|l|l|}
\hline Name of metrics & \multicolumn{1}{|c|}{ Description/formula } \\
\hline $\begin{array}{l}\text { Number of Risks } \\
\text { and Impact }\end{array}$ & $\begin{array}{l}\text { Description: No. of project's risks by impact 1,2,3,4 } \\
\text { Formula: no. of risks }\end{array}$ \\
\hline $\begin{array}{l}\text { Number of Risks } \\
\text { and Probability }\end{array}$ & $\begin{array}{l}\text { Description: No. project's risks by probability 1,2,3,4 } \\
\text { Formula: No. of risks }\end{array}$ \\
\hline $\begin{array}{l}\text { Risk priority } \\
\text { Number (RPN) }\end{array}$ & $\begin{array}{l}\text { Description: RPN assessment } \\
\text { Formula: criteria }\end{array}$ \\
\hline $\begin{array}{l}\text { Number of Risks } \\
\text { becoming impacts }\end{array}$ & Fescription: No. of project's risks that became impacts \\
\hline Tab. 3. Risk Management Plan Metrics
\end{tabular}

Records of risks and events: Risk Register Document included all information about Project risks.

\subsection{Risk Identification}

Risks were identified in the management, execution and closure process using brainstorming and checklist analysis techniques. The main categorized risks of the project planning process are:

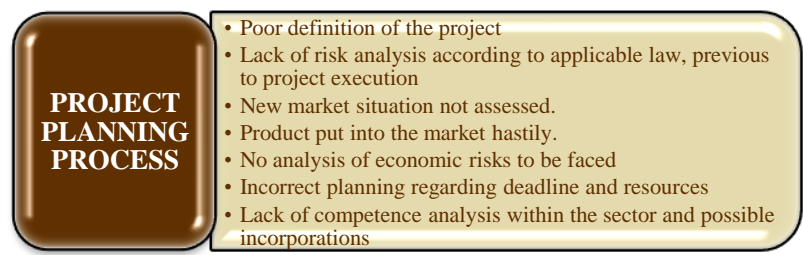

Fig. 3. Identification of Categorized Risks

2.4 Risks analysis, assessment, handling, monitoring and control

The Failure Mode \& Effect Analysis (FMEA) was the risk management key tool. A practical document containing the maximum information in the minimum space was sought. Risk assessment was been carried out based on its impact on costs, deadlines and scope, as well as level of possibility of occurrence. Figure 4 shows the scales.

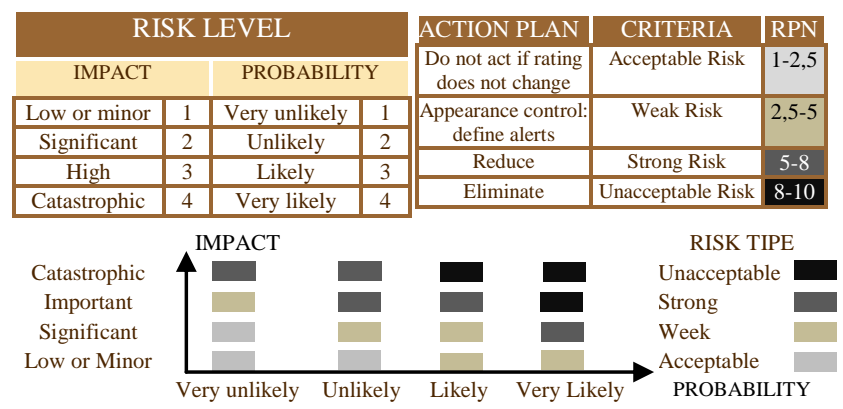

Fig. 4. Rating scales
On the one hand, the FMEA applied includes a list of risks, prioritized once assessment based on impact and probability of occurrence ratings, whose product will provide the Risk Priority Number (RPN). On the other hand, it covered the strategy to be followed to keep or reduce the number. Figure 5 shows the treatment of one of the risks.

\begin{tabular}{|c|c|c|c|c|c|c|c|}
\hline \multicolumn{8}{|c|}{ RISK IDENTIFICATION AND PRIORITIZATION } \\
\hline \multirow{2}{*}{$\begin{array}{l}\text { PROJECT } \\
\text { STAGE }\end{array}$} & \multirow{2}{*}{\multicolumn{2}{|c|}{$\begin{array}{l}\text { ASSOCIATED } \\
\text { RISKS }\end{array}$}} & \multicolumn{3}{|c|}{ IMPACT } & \multirow[t]{2}{*}{ PROBABILITY } & \multirow[t]{2}{*}{ RPN } \\
\hline & & & COST & PERIOD $S$ & SCOPE & & \\
\hline Planning & $\begin{array}{l}\text { Managemer } \\
\text { implied }\end{array}$ & nt not & 3 & 4 & 3 & 4 & 5,7 \\
\hline \multicolumn{8}{|c|}{ RISK HANDLING } \\
\hline \multirow[t]{2}{*}{ ACTION } & PEOPLE & PERIOI & \multicolumn{3}{|c|}{ IMPACT } & PROBA- & RPN \\
\hline & RESPONS. & & $\mathrm{COS}$ & PERIOD & SCOPE & E BILITY & \\
\hline $\begin{array}{l}\text { Management } \\
\text { assumes } \\
\text { leadership }\end{array}$ & Management & $\begin{array}{r}\text { Project' } \\
\text { length }\end{array}$ & 's & 2 & 2 & 2 & 0,6 \\
\hline
\end{tabular}

Fig. 5. Failure Mode \& Effect Analysis (FMEA)

Source: Sara Marcelino-Sádaba, Amaya-Ezcurdia (Dyna 2010)

\section{RESULTS \& CONCLUSIONS}

Results obtained are shown in table below:

\begin{tabular}{|c|c|c|}
\hline & THEORICAL & REAL \\
\hline Deadline & 30-day average delay & $\begin{array}{l}\text { Within the stipulated } \\
\text { period; no delays }\end{array}$ \\
\hline Price & $\begin{array}{l}1.300 .000 € \\
(22 \% \text { of turnover })\end{array}$ & $\begin{array}{l}1.300 .000 € \\
(22 \% \text { of turnover) }\end{array}$ \\
\hline Cost & $920.000 €(800.000+15 \%)$ & $864.000 €(800.000+8 \%)$ \\
\hline Benefit & $\begin{array}{l}29 \% \text { benefit } \\
\text { (cost of } 920.000 €)\end{array}$ & $\begin{array}{l}33.54 \% \text { benefit } \\
\text { (cost of } 864.000 €)\end{array}$ \\
\hline Cost increase & $15 \%$ increase from budget & $8 \%$ increase from budget \\
\hline \begin{tabular}{|l|} 
Customer \\
satisfaction
\end{tabular} & $\begin{array}{l}\text { Survey average rating of } 2 \\
\text { (scale } 2-5)\end{array}$ & $\begin{array}{l}\text { Survey average rating of } \\
4 \text { (scale } 2-5 \text { ) }\end{array}$ \\
\hline Product quality & Medium & High \\
\hline
\end{tabular}

Table 4. Results obtained

The implementation of the PMI methodology was the milestone in this project's success for a SME motivated to be consolidated in such a competitive sector and to enter a new market; and has set a turning point in its working method.

\section{ACKNOWLEDGEMENTS}

The authors would like to thank the teachers of the Engineering Projects Area, University of Vigo, and Industrias Ferri, S.A. for their cooperation and interest.

\section{REFERENCES}

Blanc-Alquier, A.M. \& Lagasse-Tignol, M.H. (2006). Risk management in small and medium-sized enterprises, Production Planning et Control.Vol.17-3 p.273-282.2006

Delisle, S. \& St-Pierre, J. (2003). SME Projects: A Software for the Identification, Assessment and Management of Risks, 48th World Conference of the International Council for Small Business (ICSB-2003)

Nagyova, A. \& Pacaiova, H. (2009). How to Build Manual for Key Performance Indicators - KPI, Chapter 15 in DAAAM International Scientific Book 2009, pp. 135-142, B. Katalinic (Ed.), Published by DAAAM International, ISBN 978-3-901509-69-8, ISSN 1726-9687,Vienna, Austria

Project Management Institute (2008). A Guide to the Project Management Body of Knowledge (PMBOK® Guide) Fourth Edition, Project Management Institute, ISBN 9781933890517, USA

Rosu, S.M.; Dragoi, G.; Guran M. \& Dragomirescu, C. (2010). The SMEs Knowledge Management: Professional Risk Assessment Using a KBS, Chapter 62 in DAAAM International Scientific Book 2010, pp. 709-724, B. Katalinic (Ed.), Published by DAAAM International, ISBN 978-3-901509-74-2, ISSN 1726-9687, Vienna, Austria 